O. MAREK SAJ CSsR

Wydział Prawa Kanonicznego

Uniwersytetu Kardynała Stefana Wyszyńskiego w Warszawie

\title{
WODA ŚWIĘCONA CZY POBŁOGOSŁAWIONA? ANALIZA PRAWNO-LITURGICZNA
}

Treść: - 1. Określenie wody w Kodeksie prawa kanonicznego z 1983 roku. - 2. Określenie wody w Mszale Rzymskim. - 3. Określenie wody w obrzędach sakramentu chrztu i małżeństwa. -4 . Określenie wody w ceremoniale liturgicznej posługi biskupów. -5 . Określenie wody w obrzędach egzorcyzmów. -6 . Określenie wody w obrzędach poświęcenia kościoła i ołtarza. - 7. Określenie wody w agendach liturgicznych. - Zakończenie.

W czasie sprawowania różnego rodzaju aktów liturgicznych bardzo często używana jest woda. Jest znakiem oczyszczenia, pokuty, ale i uświęcenia ${ }^{1}$. Zgodnie z księgami liturgicznymi, przed użyciem wody do takich czynności winna ona być najpierw pobłogosławiona. Stosuje się w tym celu odpowiednią modlitwę błogosławieństwa. Po tym akcie staje się wodą pobłogosławioną. Jednak w praktyce Kościoła w Polsce najczęściej używa się pojęcia „woda święcona”. To nie tylko uzus językowy, ale i sformułowanie widniejące w niejednej księdze liturgicznej. Warto zatem spojrzeć na to zagadnienie od strony prawno-liturgicznej, by przekonać się, jakie określenie jest najbardziej właściwe.

\footnotetext{
${ }^{1}$ Por. B. NAdolski, Liturgika, t. I: Liturgika fundamentalna, wyd. II uzupełnione, Poznań 2014, s. 249-250.
} 


\section{Określenie wody w Kodeksie prawa kanonicznego z 1983 roku}

W aktualnie obowiązującym Kodeksie prawa kanonicznego nie znajdujemy „obrzędów, jakie należy zachować w sprawowaniu czynności liturgicznych"2. Określone są one przede wszystkim w księgach liturgicznych. Nie znaczy to jednak, że Kodeks w ogóle nie uwzględnia prawa liturgicznego, bo w ten sposób pominięta by w nim została jedna z podstawowych funkcji Kościoła ${ }^{3}$. Prawodawca kodeksowy porusza interesujące nas zagadnienie $\mathrm{w}$ dwóch kanonach, nie licząc tego, w którym mowa jest o wodzie używanej przy sprawowaniu Eucharystii ${ }^{4}$. W tym przypadku jednak nie wymaga się wcześniej żadnego aktu, woda jest więc, można rzec, wodą zwykłą.

Pierwszy ze wspomnianych kanonów wymienia funkcje specjalnie powierzone proboszczowi, wśród nich błogosławienie źródła chrzcielnego, co ma miejsce podczas liturgii Wielkiej Soboty. W polskim tłumaczeniu Kodeksu prawa kanonicznego z 1983 roku czytamy: „Święcenie źródła chrzcielnego w okresie wielkanocnym". Woda używana do chrztu świętego jest zatem, według tego zapisu, wodą święconą, a akt, poprzez który się nią stała - święceniem, albo inaczej poświęcaniem. Zaglądając do łacińskiego oryginału Kodeksu, znajdziemy tam inne wyrażenie: „, fontis baptismalis tempore paschali benedictio". Mając to na uwadze, możemy powiedzieć, że woda używana do chrztu świętego jest wodą pobłogosławioną, a akt, poprzez który się nią stała, to błogosławieństwo.

\footnotetext{
${ }^{2}$ Codex Iuris Canonici auctoritate Joannis Pauli PP. II promulgatus. Kodeks Prawa Kanonicznego. Przekład polski zatwierdzony przez Konferencję Episkopatu, Pallottinum 1984 (dalej: KPK), kan. 2.

${ }^{3}$ Por. R. Sobański, Normy ogólne, w: Komentarz do Kodeksu Prawa Kanonicznego, red. J. Krukowski, R. Sobański, t. I, ks. I: Normy ogólne, Pallottinum 2003.

${ }^{4} \mathrm{KPK}$, kan. $924 \$ 1$ : „Najświętsza Ofiara eucharystyczna powinna być sprawowana $\mathrm{z}$ chleba i wina, do którego należy dodać trochę wody". Kongregacja Kultu Bożego i Dyscypliny Sakramentów, Instrukcja Redemptionis Sacramentum, o tym, co należy zachować, a czego unikać w związku z Najświętszą Eucharystią, 25 marca 2004, Poznań 2004, nr 50: „Przy sprawowaniu Mszy należy dodać do niego [wina] odrobinę wody".

${ }^{5}$ KPK, kan. 530, nr 6.
} 
Drugi kanon przywołujący „wodę” także odnosi się do sprawowania sakramentu chrztu: „Poza wypadkiem konieczności, woda używana przy udzielaniu chrztu powinna być poświęcona, zgodnie z przepisami ksiąg liturgicznych"6. Tutaj już wyraźnie akt ten nazwany został „poświęceniem”, stąd logiczne jest, że w efekcie mamy wodę święconą. Warto i w tym miejscu przywołać tekst łaciński: "Aqua in baptismo conferendo adhibenda, extra casum necessitatis, benedicta sit oportet, secundum librorum liturgicorum praescripta". Tak jak wcześniej, mówi on o błogosławieństwie, nie o poświęceniu. To żadna nowość w prawie kodeksowym. Poprzednio obowiązujące także wymagało błogosławieństwa wody, nie zaś jej poświęcenia ${ }^{7}$. To wyraźny błąd w polskim tłumaczeniu Kodeksu prawa kanonicznego z 1983 roku. Jednak praktyka używania w Kościele w Polsce wyrażenia „woda święcona” nie jest skutkiem tego błędu, gdyż sięga ona bardzo dawnych czasów.

\section{Określenie wody w Mszale Rzymskim}

Mszał Rzymski to księga liturgiczna, którą Kościół obrządku rzymskiego posługuje się podczas sprawowania Mszy świętej. Został on odnowiony, zgodnie z zaleceniami Soboru Watykańskiego $\mathrm{II}^{8}$. W roku 2002 ukazało się jego trzecie wydanie w języku łacińskim ${ }^{9}$. Ciągle czeka ono na tłumaczenie na język polski, zatem w liturgii Kościoła w Polsce używa się wydania pierwszego ${ }^{10}$ i drugiego ${ }^{11}$. W księ-

\footnotetext{
${ }^{6}$ KPK, kan. 583.

${ }^{7}$ Codex Iuris Canonici Pii X Pontificis Maximi iussu digestus Benedicti Papae XV auctoritate promulgatus, Typis Polyglottis Vaticanis 1943, kan. 530: „Functiones specialiter parocho commissae sunt quae sequuntur: $6^{\circ}$ fontis baptismalis tempore paschali benedictio, ductur processionum extra ecclesiam, necnon benedictiones extra ecclesiam solemnes”. Kan. 853: „Aqua in baptismo conferendo adhibenda, extra casum necessitatis, benedicta sit oportet, secundum librorum liturgicorum praescripta”.

${ }^{8}$ Por. Ogólne wprowadzenie do Mszału Rzymskiego, w: Mszał Rzymski dla diecezji polskich, wyd. II, poszerzone i uzupełnione, Poznań 2013, nr 1.

${ }^{9}$ Missale Romanum, editio typica tertia, Typis Vaticanis 2002.

${ }^{10}$ Mszał Rzymski dla diecezji polskich, wyd. I, Poznań 1986.

${ }^{11}$ Mszał Rzymski dla diecezji polskich, wyd. II, dz. cyt.
} 
dze tej znajdujemy kilka miejsc, gdzie jest mowa o interesującej nas tutaj, używanej w liturgii wodzie (nie licząc tej potrzebnej do sprawowania Eucharystii). Jedno z nich dotyczy błogosławieństwa wody podczas wigilii paschalnej. Celebrans odmawia wówczas modlitwę zatytułowaną „Błogosławieństwo wody chrzcielnej”12. Jest to przekład z łacińskiego Mszału Rzymskiego, w którym modlitwa ta w pierwszej edycji miała nazwę „Benedictio aquae” ${ }^{13}$, zaś w najnowszej, trzeciej, już pełną: „Benedictio aquae baptismalis” ${ }^{14}$.

Dalej, w czasie wigilii paschalnej, gdy nie ma kandydatów do chrztu ani nie błogosławi się wody chrzcielnej, błogosławi się tylko wodę do pokropienia. Ten obrzęd został nazwany „Błogosławieństwo wody do pokropienia” ${ }^{15}$, w języku łacińskim zaś: „Benedictio aquae"16. Wszędzie zatem chodzi o błogosławieństwo wody. Po nim i po odnowieniu przyrzeczeń chrzcielnych wierni zostają pokropieni pobłogosławioną wcześniej wodą. W polskim przekładzie Mszału w rubrykach do tego aktu czytamy natomiast: „Kapłan kropi lud wodą święconą"17. Taki komentarz widnieje w poprzednim i obecnym wydaniu. Brzmienie łacińskie jest jednak inne: „Sacerdos aspergit populum aqua benedicta"18.

W czasie Mszy świętej, w dniu Pańskim, a zwłaszcza w okresie wielkanocnym, „zamiast zwykłego aktu pokuty może się odbyć błogosławieństwo wody i pokropienie nią wiernych na pamiątkę

\footnotetext{
${ }^{12}$ Mszał Rzymski dla diecezji polskich, wyd. I, dz. cyt., s. 174; Mszał Rzymski dla diecezji polskich, wyd. II, dz. cyt., s. 174.

${ }^{13}$ Missale Romanum, editio typica, Typis Polyglottis Vaticanis MCMLXX, s. 283.

${ }^{14}$ Missale Romanum, editio typica tertia, dz. cyt., s. 364.

${ }^{15}$ Mszał Rzymski dla diecezji polskich, wyd. I, dz. cyt., s. 177; Mszał Rzymski dla diecezji polskich, wyd. II, dz. cyt., s. 177.

${ }^{16}$ Missale Romanum, editio typica, dz. cyt., s. 285; Missale Romanum, editio typica tertia, dz. cyt., s. 369.

${ }^{17}$ Mszał Rzymski dla diecezji polskich, wyd. I, dz. cyt., s. 179; Mszał Rzymski dla diecezji polskich, wyd. II, dz. cyt., s. 179.

${ }^{18}$ Missale Romanum, editio typica, dz. cyt., s. 287; Missale Romanum, editio typica tertia, dz. cyt., s. 373.
} 
chrztu” ${ }^{19}$. W dodatku do Mszału Rzymskiego znajdujemy „Obrzęd poświęcenia wody i pokropienia wiernych" ${ }^{\text {20 }}$. To kolejne miejsce w Mszale, gdzie mowa jest o wodzie. W uwagach dla kapłana przy tym obrzędzie czytamy: „Po pozdrowieniu wiernych kapłan stojąc przy krześle i mając przed sobą naczynie $\mathrm{z}$ wodą, która ma być poświęcona, zwrócony do ludu zachęca go do modlitwy słowami niżej podanymi lub podobnymi"21. W wydaniu łacińskim Mszału zauważamy jednak jak poprzednio inną nazwę tego obrzędu: „Ordo ad faciendam et aspergendam aquam benedictam" ${ }^{22}$. Łaciński komentarz do tej liturgicznej czynności także używa innych pojęć niż jego polski przekład: „Post salutationem, sacerdos, stans ad sedem, ad populum conversus, habens ante se vas cum aqua benedicenda, populum ad orandum invitat his vel similibus verbis"23.

Krótko zatem trzeba powiedzieć, że polskie tłumaczenie Mszału Rzymskiego, poza małymi wyjątkami, ciągle stosuje pojęcie „woda święcona”, a obrzęd dokonywany nad nią to „poświęcenie”.

\section{Określenie wody w obrzędach sakramentu chrztu i małżeństwa}

Jeśli chodzi o święte sakramenty, wody używa się przy sprawowaniu sakramentu chrztu i małżeństwa. Przypomnijmy, że o wodzie używanej w obrzędzie udzielania chrztu była już mowa przy okazji

${ }^{19}$ Ogólne wprowadzenie do Mszału..., dz. cyt., nr 51. Tutaj warto wspomnieć, iż to ogólne wprowadzenie znajdujące się w wydaniu łacińskim w punkcie mówiącym o akcie pokuty także wspomina o błogosławieństwie wody: „Die dominica, praesertim tempore paschali, loco consueti actus paenitentialis, quandoque fieri potest benedictio et aspersio aquae in memoriam baptismi”. Missale Romanum, editio typica tertio, dz. cyt., nr 51.

${ }^{20}$ Mszał Rzymski dla diecezji polskich, wyd. I, dz. cyt., s. (2); Mszał Rzymski dla diecezji polskich, wyd. II, dz. cyt., s. (2).

${ }^{21}$ Mszał Rzymski dla diecezji polskich, wyd. I, dz. cyt., s. (2); Mszał Rzymski dla diecezji polskich, wyd. II, dz. cyt., s. (2).

${ }^{22}$ Missale Romanum, editio typica, dz. cyt., s. 889; Missale Romanum, editio typica tertia, dz. cyt., s. 1249.

${ }^{23}$ Missale Romanum, editio typica, dz. cyt., s. 889; Missale Romanum, editio typica tertia, dz. cyt., s. 1249. 
analizy tej kwestii w Kodeksie prawa kanonicznego z 1983 roku. W Kościele w Polsce przy tym sakramencie stosuje się księgę Obrzędy chrztu dzieci $i^{24}$ oraz w przypadku chrztu dorosłych Obrzędy chrześcijańskiego wtajemniczenia dorosłych ${ }^{25}$. Woda ma w tym rytuale ważne miejsce, ponieważ trzykrotne polanie nią należy do jego podstawowych elementów. W czasie liturgii tego sakramentu (poza okresem wielkanocnym, gdyż wtedy używa się wody pobłogosławionej podczas liturgii Wielkiej Soboty) celebrans dokonuje błogosławieństwa wody chrzcielnej. W Obrzędach wydanych dla diecezji polskich czynność ta została nazwana „poświęceniem wody” ${ }^{26}$. W innych miejscach, gdzie mowa jest o tej wodzie, określana jest ona albo „chrzcielną”, albo „poświęconą"27, albo zwyczajnie „wodą"28. Z kolei w wydaniu typicznym Obrzędów chrztu widnieją wyrażenia „aqua baptismalis”29, „aqua benedicta” ${ }^{30}$ oraz „aqua”31. Różnica zatem w obydwu wersjach językowych dotyczy jedynie wody pobłogosławionej, przetłumaczonej na język polski jako „poświęcona”. Tutaj warto zaznaczyć, że o wodzie używanej w czasie obrzędu chrztu wspomina soborowa konstytucja o liturgii świętej Sacrosanctum Concilium, gdzie czytamy: „Poza okresem wielkanocnym wodę chrzcielną można pobłogosławić w czasie obrzędu chrztu, posługując się zatwierdzoną formułą

\footnotetext{
${ }^{24}$ Obrzędy chrztu dzieci dostosowane do zwyczajów diecezji polskich, wyd. III, Katowice 2006.

${ }^{25}$ Obrzędy chrześcijańskiego wtajemniczenia dorosłych dostosowane do zwyczajów diecezji polskich, Katowice 1988.

${ }^{26}$ Obrzędy chrztu dzieci..., dz. cyt., s. 39, 41, 42, 64, 66, 68, 87. Rytuał stosowany przy chrzcie dorosłych także nazywa tę czynność „poświęceniem wody”; Obrzędy chrześcijańskiego wtajemniczenia dorosłych..., dz. cyt., s. 102.

${ }^{27}$ Zob. Obrzędy chrztu dzieci..., dz. cyt., s. 42, 43, 44, 67, 68, 69, 88, 99, 100. Rytuał stosowany przy chrzcie dorosłych używa wyrażenia „woda chrzcielna poświęcona”; Obrzędy chrześcijańskiego wtajemniczenia dorosłych..., dz. cyt., s. 102, 120.

${ }^{28}$ Obrzędy chrztu dzieci..., dz. cyt., s. 41, 42, 46, 47, 67, 71, 72, 87, 91, 103, 109; Obrzędy chrześcijańskiego wtajemniczenia dorosłych..., dz. cyt., s. 105, 122, 134, 164.

${ }^{29}$ Zob. Ordo baptismi parvulorum, editio typica altera, Liberia Editrice Vaticana MCMLXXXVI, s. 29, 42.

${ }^{30}$ Tamże, s. 52, 61, 62.

31 Tamże, s. 29, 32, 44, 54, 64, 70.
} 
skróconą" ${ }^{32}$. Natomiast wcześniejsze tłumaczenie dokumentów soborowych mówiło o poświęceniu wody chrzcielnej ${ }^{33}$. Z kolei tekst łaciński konstytucji brzmi: „Aqua baptismalis, extra tempus paschale, in ipso ritu Baptismi probata formula breviore benedici potest”. Jak łatwo zauważyć, aktualne tłumaczenie poprawnie oddaje znaczenie łacińskiego oryginału ${ }^{34}$.

Innym sakramentem, w którym używa się wody, jest sakrament małżeństwa. Po wyrażeniu przez nupturientów zgody małżeńskiej ma miejsce nałożenie obrączek, poprzedzone ich błogosławieństwem ${ }^{35}$. Polskie wydanie Obrzędów tego sakramentu określa to następująco: „Kapłan kropi obrączki wodą święconą " ${ }^{36}$, i jeszcze w dwóch innych miejscach: „Celebrans kropi obrączki wodą święconą” ${ }^{37}$. W typicznym wydaniu tej księgi liturgicznej nie ma wprost mowy o wodzie, ale znajdujemy tam zdania: „Pro opportunitate, anulos aspergit et tradit sponsis”38 oraz „Et, pro opportunitate, anulos aspergit et tradit sponsis" ${ }^{39}$. Według uznania, jest więc przewidziane pokropienie w domyśle chodzi oczywiście o wodę, bez określenia jaką. Warto tutaj zauważyć, iż w pierwszym posoborowym wydaniu Obrzędów nie ma wzmianki o pokropieniu obrączek. Mowa jest tylko o ich błogosławieniu ${ }^{40}$.

\footnotetext{
${ }^{32}$ Sobór WAtykański II, Konstytucja o liturgii świętej Sacrosanctum Concilium, w: tenże, Konstytucje - Dekrety - Deklaracje, Poznań 2002, nr 70.

${ }^{33}$ Por. SobóR WATy Kański II, Konstytucja o liturgii świętej Sacrosanctum Concilium, w: tenże, Konstytucje - Dekrety - Deklaracje, Poznań 1967, nr 70.

${ }^{34}$ Concilum Vaticanum II, Constitutio de sacra liturgia, http://www.vatican.va/ archive/hist_councils/ii_vatican_council/documents/vat-ii_const_19631204_sacrosanctum-concilium_lt.html (dostęp: 4.02.2016).

${ }^{35}$ Obrzędy sakramentu małżeństwa dostosowane do zwyczajów diecezji polskich, wyd. trzecie według drugiego wydania wzorcowego, Katowice 2003, s. 33.

${ }^{36}$ Tamże, s. 34.

${ }^{37}$ Tamże, s. 45, 60 .

${ }^{38}$ Ordo celebrandi matrimonium, editio typica altera, Typis Polyglottis Vaticanis MCMXCI, s. 19, 34.

${ }^{39}$ Tamże, s. 50, 60 .

${ }^{40}$ Zob. Ordo celebrandi matrimonium, editio typica, Typis Polyglottis Vaticanis MCMLXXII, s. 13, 19, 24.
} 


\section{Określenie wody w ceremoniale liturgicznej posługi biskupów}

W 2010 roku ukazał się w języku polskim ceremoniał liturgicznej posługi biskupów ${ }^{41}$. Jest to tłumaczenie łacińskiego, typicznego wydania $^{42}$. Nie jest to księga stricte liturgiczna, gdyż nie jest przeznaczona do używania podczas sprawowanej liturgii. Ma jedynie służyć pomocą biskupowi, jak i innym posługującym w celebracjach liturgicznych ${ }^{43}$. Interesujące nas tutaj zagadnienie „wody” występuje w niej aż w 41 miejscach. Od razu należy zaznaczyć, iż nie znajdziemy tam określenia „woda święcona” ani „poświęcona”, lecz jedynie „pobłogosławiona”.

Ceremoniał, opisując posługę biskupa w danej liturgii, wśród potrzebnych przedmiotów, które należy przygotować, wymienia również wodę pobłogosławioną ${ }^{44}$. W kilku innych miejscach księga ta podkreśla, iż biskup „żegna się przy pomocy kropidła umoczonego w pobłogosławionej wodzie" ${ }^{45}$. Taką wodą żegnają się również inni wierni ${ }^{46}$. Najwięcej sytuacji dotyczy jednak używania wody pobłogosławionej do pokropienia wiernych ${ }^{47}$ lub przedmiotów ${ }^{48}$. Warto także wspomnieć, że szósty tytuł rozdziału czwartego

${ }^{41}$ Ceremoniał liturgicznej posługi biskupów dostosowany do zwyczajów diecezji polskich, wyd. wzorcowe, Katowice 2010.

${ }^{42}$ Ceremoniale Episcoporum, editio typica, Typis Polyglottis Vaticanis MCMLXXXIV.

${ }^{43}$ Por. Kongregacja Kultu Bożego, Dekret, Prot. N. CD 1300/84, w: Ceremoniał liturgicznej posługi biskupów..., dz. cyt., s. 6 .

${ }^{44}$ Zob. Ceremoniał liturgicznej posługi biskupów..., dz. cyt., nr 125a, 618b, 839b, 862, 889b, 945, 974, 1015, 1041, 1054, 1073, 1090,

${ }^{45}$ Tamże, nr 79. Zob. także: nr 111, 1158, 1196.

46 Tamże, nr 110.

${ }^{47}$ Tamże, nr 376: „kropi lud wodą pobłogosławioną”; nr 1023: „wodą z nowo pobłogosławionego źródła chrzcielnego kropi wiernych".

${ }^{48}$ Tamże, nr 245: „kropi świece wodą pobłogosławioną”; nr 256: „kropi popiół wodą pobłogosławioną”; nr 267: „kropi gałązki pobłogosławioną wodą”; nr 851 i 853 : „kropi trumnę wodą pobłogosławioną”; nr 874: „pobłogosławioną wodą kropi plac pod kościół”; nr 996 i 1102: „kropi ołtarz wodą pobłogosławioną”; nr 1046: „kropi dzwon pobłogosławioną wodą”; nr 1058: „kropi koronę (korony) pobłogosławioną wodą”; nr 1080: „kropi pobłogosławioną wodą cmentarz”. 
części pierwszej ceremoniału został zatytułowany „Używanie wody pobłogosławionej" ${ }^{49}$.

Porównując wszystkie zapisy polskiego wydania ceremoniału z łacińskim, krótko należy stwierdzić, że w tym drugim wszędzie widnieje „aqua benedicta” ${ }^{50}$. Polski odpowiednik jest więc wiernym tłumaczeniem oryginału.

\section{Określenie wody w obrzędach egzorcyzmów}

Zgodnie z Katechizmem Kościoła katolickiego, „egzorcyzmy mają na celu wypędzenie złych duchów lub uwolnienie od ich demonicznego wpływu, mocą duchowej władzy, jaką Jezus powierzył Kościołowi" ${ }^{51}$. Do tego obrzędu używany jest rytuał zatytułowany Egzorcyzmy i inne modlitwy błagalne ${ }^{52}$. Do podstawowych gestów i rytów egzorcyzmów należy znak krzyża, nałożenie rąk, tchnięcie oraz pokropienie pobłogosławioną wodą ${ }^{53}$. Wodę tę egzorcysta sam może wcześniej pobłogosławićs ${ }^{54}$. Obrzędy te wymieniają wodę jeszcze w trzech innych miejscach, nazywając ją „pobłogosławioną": „Prosimy Cię, Panie, spraw, niech wszędzie tam, gdzie padną krople tej pobłogosławionej wody..." ${ }^{55}$, „Oto pobłogosławiona woda” ${ }^{56}$ oraz „Kapłan kropi miejsce pobłogosławioną wodą"57. Nigdzie w tekście polskim nie używa się innej nazwy. Jest on zatem wiernym tłumaczeniem oryginału, De exorcismis et supplicationibus quibusdam ${ }^{58}$, gdzie

${ }^{49}$ Tamże, s. 46.

${ }^{50}$ Ceremoniale Episcoporum, dz. cyt., np. nr 256: „Postea aspergit cineres aqua benedicta”; nr 981: „Deinde Episcopus aspergit altare aqua benedicta et illud incensat”; nr 1030: „Postea campanam aspergit aqua benedicta, et incensat”.

${ }^{51}$ Katechizm Kościoła katolickiego, 11 października 1992, Poznań 1994, nr 1673.

${ }^{52}$ Egzorcyzmy i inne modlitwy błagalne, Katowice 2002.

${ }^{53}$ Por. Wprowadzenie teologiczne i pastoralne, w: Egzorcyzmy..., dz. cyt., nr 20.

${ }^{54}$ Por. Egzorcyzmy..., dz. cyt., nr 41.

55 Tamże, nr 43.

56 Tamże, nr 44.

${ }^{57}$ Błaganie i egzorcyzm, które moga być stosowane w szczególnych okolicznościach życia Kościoła, w: Egzorcyzmy..., dz. cyt., nr 12.

${ }^{58}$ Congregatio de Cultu Divino et Disciplina Sacramentorum, De exorcismis et supplicationibus quibusdam, 22 listopada 1998. 
jest mowa właśnie o wodzie pobłogosławionej. Co ciekawe, patrząc na obrzędy egzorcyzmów obowiązujące wcześniej, jeszcze przed reformą soborową, również zauważamy w nich określenie „woda pobłogosławiona” ${ }^{59}$, nie zaś „święcona”. Nie jest ono zatem nowością okresu reformy liturgicznej mającej miejsce po Soborze Watykańskim II, ale funkcjonowało w liturgii i prawie Kościoła dużo wcześniej.

\section{Określenie wody w obrzędach poświęcenia kościoła i ołtarza}

Zagadnienie poświęcenia kościoła i ołtarza omawia księga liturgiczna Obrzędy poświęcenia kościoła i ołtarza ${ }^{60}$. Jest ona tłumaczeniem na język polski typicznego łacińskiego wydania ${ }^{61}$. Zgodnie z wersją polską, podczas tych obrzędów stosuje się wodę święconą. Jest o tym mowa w kilkunastu miejscach, na przykład przy wymienianiu rzeczy potrzebnych przy tych obrzędach ${ }^{62}$. Dalej, Obrzędy zamieszczają modlitwę nad wodą, nazywając ją modlitwą błogosławieństwa wody ${ }^{63}$. W innych z kolei miejscach, gdzie przewidziane jest użycie wody przez szafarza obrzędu, widnieje sformułowanie „woda święcona”: „biskup (...) święconą wodą kropi plac” ${ }^{64}$, „opuszcza się obrzęd pokropienia wodą święconą" ${ }^{\text {", }}$, „biskup kropi ołtarz wodą święconą" ${ }^{66}$. Czasem natomiast nie ma tego dodatkowego określenia: „biskup (...) idzie przez nawę kościoła, kropiąc wodą lud i ściany”67,

${ }^{59}$ De exorcizandis obsessis a daemonio, w: Rituale Romanum, editio typica 1952, Libreria Editrice Vaticana 2008, s. 850, 851, 886.

${ }^{60}$ Obrzędy poświęcenia kościoła i ołtarza, wyd. wzorcowe, Katowice 2001.

${ }^{61}$ Sacra Congregatio pro SaCramentis et Cultu Divino, Ordo dedicationis ecclesiae et altaris, 29 maja 1977, w: Posoborowe prawodawstwo kościelne, dokumenty prawno-liturgiczne, zebrał i przetłum. E. Sztafrowski, t. XI, z. 1, Warszawa 1980, s. 162-270.

${ }^{62}$ Zob. Obrzędy poświęcenia kościoła..., dz. cyt., rozdz. I, nr 7. Są też miejsca, gdzie wśród tych rzeczy wymieniana jest woda, ale bez określenia „święcona”. Zob. np. rozdz. II, nr 21; rozdz. IV, nr 27; rozdz. V, nr 5.

${ }^{63}$ Tamże, rozdz. II, nr 42, 48; rozdz. III, nr 8; rozdz. IV, nr 17, 35; rozdz. V, nr 10-13.

${ }^{64}$ Tamże, rozdz. I, nr 25.

65 Tamże, rozdz. III, nr 2c.

66 Tamże, rozdz. VI, nr 10.

${ }^{67}$ Tamże, rozdz. II, nr 49. 
lub: „biskup kropi wodą tylko lud”68. Jak łatwo zauważyć, modlitwa nad wodą jest modlitwą błogosławieństwa, natomiast woda po niej nazywana jest święconą. Nie ma tu więc konsekwencji.

Dla dopełnienia obrazu tutaj również należy sięgnąć do typicznego wydania Obrzędów poświęcenia kościoła i ołtarza, nade wszystko tam, gdzie w wydaniu polskim pojawia się wyrażenie „woda święcona”. W tych miejscach oryginału widnieje jednak „woda błogosławiona”; dla przykładu: „Pro ritus celebratione parentur: (...) vas aquae benedictae cum aspersorio” ${ }^{69}$, „Postea, resumpta mitra, Episcopus aqua benedicta aspergit aream novae ecclesiae" ${ }^{\prime 70}$ lub też „Tuno, pro opportunitate, Episcopus aspergit lapidem aqua benedicta eumque incensat" ${ }^{\text {71 }}$. Jak widać, jest to znowu problem przekładu. Jedynym poprawnym wyrażeniem w polskich obrzędach jest bowiem „błogosławieństwo wody”, które dokładnie odpowiada łacińskiemu „benedictio aquae”72.

\section{Określenie wody w agendach liturgicznych}

Analizując zagadnienie „wody” używanej podczas obrzędów liturgicznych, warto także sięgnąć do księgi zawierającej zbiór najczęściej stosowanych w praktyce pastoralnej Kościoła modlitw, nabożeństw i błogosławieństw. Taką księgę posiada niemalże każda diecezja. Tutaj pod uwagę zostaną wzięte dwie wydane w ostatnich latach: jedna $z$ diecezji opolskiej ${ }^{73}$, druga $z$ tarnowskiej ${ }^{74}$. Ponieważ są to nowe opracowania, interesujące będzie użycie w nich wyrażenia „woda święcona”, gdyż funkcjonowało ono zwłaszcza w Agendzie diecezji opolskiej, powszechnie stosowanej w wielu kościołach ${ }^{75}$.

\footnotetext{
${ }^{68}$ Tamże, nr 9.

${ }^{69}$ Sacra Congregatio pro Sacramentis et Cultu Divino, Ordo dedicationis..., dz. cyt., rozdz. I, nr 7 .

${ }^{70}$ Tamże, nr 25.

${ }^{71}$ Tamże, nr 27.

${ }^{72}$ Zob. tamże, np. rozdz. II, nr 48; rozdz. III, nr 8.

${ }^{73}$ Agenda liturgiczna, wyd. nowe i poszerzone, Opole 2013.

${ }^{74}$ Agenda liturgiczna, wyd. III (poprawione i uzupełnione), Tarnów 2013.

${ }^{75}$ Agenda liturgiczna diecezji opolskiej. Nabożeństwa, poświęcenia i błogosławieństwa, wyd. studyjne, Opole 1981, np.: „Udzielający błogosławieństwa kropi
} 
Z przedmowy do nowo wydanej Agendy liturgicznej diecezji opolskiej dowiadujemy się, że „przed przystąpieniem do przeredagowania dotychczasowej Agendy przeprowadzono konsultacje i zapoznano się z opiniami i postulatami kapłanów z różnych regionów diecezji opolskiej i gliwickiej”, a „ostatecznej wersji opracowania i zredagowania dokonali pracownicy Instytutu Liturgii, Muzyki i Sztuki Sakralnej Wydziału Teologicznego Uniwersytetu Opolskiego"76. Można by zatem się spodziewać, że używane w niej będą właściwe terminy. Niestety, nadal funkcjonuje tu określenie „woda święcona”. Oto niektóre przykłady: „Celebrans kropi wodą święconą obecnych oraz kredę i kadzidło"77; „Szafarz w milczeniu kropi pokarmy wodą święconą"78; „Na koniec można jeszcze pokropić dzieci wodą święconą"79; „Jeśli poświęca się nowy dom, kapłan może przejść przez wszystkie jego pomieszczenia i pokropić je wodą święconą" ${ }^{80}$; „Następnie może pokropić obecnych wodą święconą"81.

Można pytać, dlaczego w nowym wydaniu tej liturgicznej księgi wciąż pozostało niepoprawne wyrażenie. Pewnego rodzaju usprawiedliwienia można doszukać się w jej źródłach. Otóż przy opracowywaniu nabożeństw tam zamieszczonych uwzględniono dwutomowe wydanie Obrzędów błogosławieństw dostosowanych do zwyczajów

w milczeniu pokarmy wodą święconą”, s. 409; „Kapłan poświęca różaniec wodą święconą”, s. 425; „Kapłan poświęca modlitewniki wodą święconą”, s. 433; „Kapłan żegna się wodą święconą i kropi nią obecnych", s. 435.

${ }^{76}$ Przedmowa, w: Agenda liturgiczna, wyd. nowe i poszerzone, dz. cyt., s. 5.

${ }^{77}$ Agenda liturgiczna, wyd. nowe i poszerzone, dz. cyt., s. 595.

${ }^{78}$ Tamże, s. 605.

79 Tamże, s. 627.

${ }^{80}$ Tamże, s. 634. Tutaj, niejako na marginesie tych rozważań, warto zwrócić uwagę, iż niewłaściwe jest też wyrażenie „poświęcenie domu”, gdyż domy się błogosławi. Zob. Obrzędy błogosławieństw dostosowane do zwyczajów diecezji polskich, t. 1, Katowice 1994, nr 474-491. Z drugiej jednak strony, analizowana Agenda poprawnie nazwała ten obrzęd: „Błogosławieństwo nowego domu albo mieszkania” (s. 629). Jest zatem niekonsekwentna, raz mówiąc o błogosławieństwie, a innym razem o poświęceniu domu.

${ }^{81}$ Agenda liturgiczna, wyd. nowe i poszerzone, dz. cyt., s. 667. 
diecezji polskich ${ }^{82}$, co zostało odnotowane we wprowadzeniu ${ }^{83}$. Obrzędy te używają właśnie określenia „woda święcona”, tak we wprowadzeniu teologicznym i pastoralnym ${ }^{84}$, jak i przy poszczególnych błogosławieństwach ${ }^{85}$, co oczywiście nie jest poprawne, gdyż już obrzędy błogosławieństw zawarte w przedsoborowym Rytuale Rzymskim stosowały pojęcie „aqua benedicta” ${ }^{\text {. }}$.

Dla porównania warto również zobaczyć, jak interesująca nas tutaj kwestia wygląda w wydanej w tym samym czasie agendzie diecezji tarnowskiej. Ona także przy różnego rodzaju błogosławieństwach nakazuje używać „wody święconej”, na przykład: „Celebrans kropi wieńce wodą święconą"87, „Kapłan kropi wino wodą święconą"88, „Teraz szafarz kropi zebranych i wianki wodą święconą"89 , „Celebrans kropi dewocjonalia wodą święconą"90.

\section{Zakończenie}

Zaprezentowana powyżej analiza prawno-liturgiczna dotycząca pojęciowego określania używanej w liturgii Kościoła wody stanowi ogólne spojrzenie na to zagadnienie. Z pewnością wymaga ono bardziej pogłębionego studium. Jednak dokonane tutaj badania pozwalają stwierdzić, iż wyrażenie „aqua benedicta” obecne w typicznych wydaniach ksiąg liturgicznych ich polskie tłumaczenia oddają

${ }^{82}$ Zob. Obrzędy błogosławieństw dostosowane do zwyczajów diecezji polskich, t. 1 i 2, Katowice 1994.

${ }^{83}$ Por. Wprowadzenie duszpasterskie, w: Agenda liturgiczna, wyd. nowe i poszerzone, dz. cyt., s. 7.

${ }^{84}$ Wprowadzenie teologiczne i pastoralne, w: Obrzędy błogosławieństw..., dz. cyt., t. 1, nr 26: „Najczęściej są stosowane następujące znaki: rozłożenie, podniesienie, złożenie lub nałożenie rąk, znak krzyża, pokropienie wodą święconą, okadzenie”.

${ }^{85}$ Zob. Obrzędy błogosławieństw..., dz. cyt., t. 1, nr 471, 489, 511, 534, 553; Obrzędy błogosławieństw..., dz. cyt., t. 2, nr 957, 1048, 1096, 1154, 1346.

${ }^{86}$ Zob. Benedictiones quibusdam diebus infra annum impertiendae, w: Rituale Romanum, editio typica 1952, Libreria Editrice Vaticana 2008, s. 400-754.

${ }^{87}$ Agenda liturgiczna, wyd. III (poprawione i uzupełnione), dz. cyt., s. 467.

${ }^{88}$ Tamże, s. 473.

89 Tamże, s. 485.

90 Tamże, s. 505. 
najczęściej jako „woda święcona” lub „poświęcona”. Rzadko kiedy funkcjonuje termin „woda pobłogosławiona”. W zasadzie stosują je tylko dwie księgi, mianowicie Ceremoniał liturgicznej posługi biskupów oraz Obrzędy egzorcyzmów. Trudno znaleźć przyczynę, dla której w polskiej rzeczywistości kościelnej tak mocno zakorzeniło się nieprawidłowe określenie; być może dlatego, że tak właśnie było to zapisane w księgach liturgicznych. Aktualnie nie chodzi o to, by jakby na siłę próbować je wyeliminować z praktyki pastoralnej, choć z drugiej strony z pewnością byłoby dobrze używać prawidłowego nazewnictwa i w ten sposób formować wiernych świeckich. Już sama świadomość niepoprawności tych wyrażeń, zwłaszcza u duchownych, byłaby dużym osiągnięciem.

\section{Holy or blessed water? Legal and liturgical analysis}

During celebration of a different kind of liturgical acts water is used frequently. According to liturgical acts water should be previously blessed with the appriopriate prayer. After that act of prayer water becomes blessed water. However, within the Church the notion ",holy water” is widely applied. Legal and liturgical research shows that the only proper phrase is ,aqua benedicta" - blessed water. It is difficult to explain why that improper notion "holy water" is so strongly rooted in Polish reality. Probably it derives from the fact that the phrase "holy water" is introduced in liturgical books. It seems necessary to provide formation for both laity and clergymen to make them aware of the fact why the notion "blessed water" is the only proper one.

SŁOWA KLUCzOWE: woda pobłogosławiona, księgi liturgiczne, używanie wody podczas liturgii.

KEYwORDs: blessed water, Liturgical books, using water during liturgy.

Nota o Autorze:

O. DR HAB. MARek SaJ CSsR- prodziekan Wydziału Prawa Kanonicznego Uniwersytetu Kardynała Stefana Wyszyńskiego w Warszawie, kierownik Katedry Kanonicznego Prawa Karnego. 